\title{
DIGESTIBILITY AND SOME PERFORMANCE PARAMETERS FOR SHEEP FEEDING ON DATE SEED TREATED WITH BACTERIA
}

\author{
Shimaa S. Salama, Etab R.I. Abd El-Galil and El-Bordeny N.E. \\ Animal Production Dept., Fac. of Agric., Ain Shams Univ., P.O. Box 68 Hadyek Shoubra11241, \\ Cairo, Egypt \\ *Corresponding author: selimshimaa@yahoo.com
}

[38]

Received 11 December, 2018, $\quad$ Accepted 20 January, 2019

\begin{abstract}
This paper focuses on treated date seed with two cellulolytic bacteria (Acetobacter xylinum and Thermonospora fusca) isolated from sheep and evaluated these species by Invitro gas production and metabolism trail. We evaluated the influence of many rations contain several percentage from date seed untreated and treated on In vitro traild for DM,OM, NDF, ADF, cellulose and hemicellulose disappeara (samples incubated for $24 \mathrm{hrs}$ ). the best ration used in metabolism trail .

The experimental work was conducted in 2017, at the Department of Animal Production, faculty of agriculture, Ain Shams University, Cairo, Egypt and the experiment of the farm animals occurred in the Animal Production research institute.

Our results in this revealed that the ration content $25 \%$ untreated and treated with bacteria had significant values on NDF, ADF and hemicellulose degradability after 24 hours, especially treatment 2 (Thermonospora fusca) of date seed. In the experimental ration with ascending level of untreated and treated date seed had not significant effect on $\mathrm{pH}$ value while more effect on total gas production (GP),ammonia, TVFA's, MP, EMP and metabolizable energy ME (Mcal/g). The differences were significant $(P<0.05)$ between control ration and other experimental rations. Furthermore, ration content date seed treated (R3) had the highest values of DM, OM, CF and EE digestibility. It could be noticed that improving $\mathrm{CP}, \mathrm{CF}$ and cell wall constituents (NDF, ADF, hemicellulose and cellulose) digestibility may be due to the increasing number of rumen cellulolytic bacteria.

In conclusion, the bacterial treatment (Acetobacter xylinum and Thermonospora fusca) with date seed successfully to improve chemical compostion of date seed and Invitro digestiability specially ration contain $25 \%$ from total dry matter. It showed that the strain (Thermonospora fusca) was
\end{abstract}

the best in In vitro fermentation. Digestibility indicated that ration contain treated date seed (R3) was high DM, OM, ADF and nitrogen than other rations. It was concluded that treated date seed can replace concentrate in rations and improve In vitro degradability, digestibility trail and no effect on rumen and blood parameters without adversely affecting on helthy animals.

Key words: date seeds, Bacteria, sheep, In vitro gas production, Digestibility, Rumen parameters.

\section{INTRODUCTION}

Many research trends are to explore the use of waste from food industry and the waste utilization could provide economic gain to the farmers, industry, food security, environmental safety and sustainability. Date-pits are generally used as complementary feed materials for animals and poultry or as a conventional soil fertilizer. The world production of dates was 7.5 million tons Guizani et al (2014), meaning that approximately 750 thousand tons of date seeds were produced during that year. A large number of date seeds are being obtained from the date industries or the waste products annually. Date seeds contain high levels of valuable bioactive compounds and dietary fiber which makes them suitable for the preparation of fiberbased foods Al-Farsi and Lee (2014). Hence, utilization of this low cost agricultural by-product is important to date industry in the date producing countries.

Many studies have been carried out on date seeds, (Basuni and AL-Marzooq, 2010) reported that date seeds are commonly used as cheap source of energy in animal rations under desert condition, being available in abundance all over the year. Date seeds, also called pits, kernels, stones or pips, are a waste product of date processing and packing plants. Therefore, date seeds 
have been a problem to the date industry, while they contain many valuable substances such as carbohydrates, oil, dietary fiber, protein, bioactive polyphenols and natural antioxidants. However, date seeds can be used for many applications like food products formulation, cosmetics and functional and medicinal supplements Golshan et al (2017). The seed forms about 10 to $30 \%$ of fruit weight,large amounts of date seeds are commonly used in desert areas as a source of feed energy. It is cheap and can be offered to animals in crushed or ground form. The chemical composition of date seeds showed, the contents of DM, CP, CF, EE, NFE, Ash, NDF, ADF, ADL, Hemicelluloses and cellulose were around ( $88.2 ; 6.1 ; 7.7 ; 2.9 ; 55.2$; $1.0 ; 50.6 ; 40.6 ; 7.0 ; 6.4$ and $25.9 \%$ ), respectively.

El-Shaer et al (2004) found that using date stone with silage instead of berseem hay as a basal diets did not significantly affect the digestibility of DM, CP, EE, NFE and OM. Digestion coefficient of CF was affected by the type of fattening diets. The maximum digestibility coefficients of NDF, ADF and ADL were recorded in date stone diet. Also, indicated that the halophytic silage supplemented with ground date seeds can be recommended as a non-conventional fattening diet for sheep due to its nutrition and economic potentials. Al-Ani and Farhan (2009) fed Awassi lambs diets contained $62 \%$ date stone with different sources of nitrogen (soy bean meal, cotton seed meal and urea) and indicated that there was no significant difference in dry matter feed intake. Al-Shanti et al (2013) concluded that substitution of corn and barely by crushed date seeds up to $50 \%$ can be used to improve the growth performance of Assaf lambs.

The biological treatments of crop residues to improve the accessibility of cellulosic fractions, thus improving their digestibility and feeding value have been attracting the extensive interests among researchers (Yu et al 2009) although this process has a long history. The major obstruction in biological conversion of lignocelluloses is the physical protection of cellulose by lignin against cellulolytic enzymes. The potential of biological treatments has been explained by the ability of certain microbes (specifically bacteria or fungi) to disrupt plant cell wall by partial breakdown of the lignincarbohydrate complex Keller et al (2003) thus improving their utilization in the rumen by increasing the availability of fermentable energy to ruminal microbes Akin et al (1996). Gado and Abd ElGalil (2009) reported that Acetobacter xylinum isolated from sheep recorded the highest value of DM disappearance $(61.8 \%)$ then that isolated from camels $(60.2 \%)$ or buffalo $(59.4 \%)$ while the lowest value was recorded for cow $(58.6 \%)$. In similar trend the highest value found for Thermonospora fusca isolated from sheep was $61.7 \%$ while the lowest value found in buffalo (51.3\%).
The main goals of the present research are to compare effect of two strains of fibrolytic bacteria isolated from rumen of sheep (Acetobacter xylinum and Thermonospora fusca) on chemical composition, cell wall constituents of treated date seeds compared with untreated. It also compares effect of replacement of DM of concentrate feed mixture (CFM) in rations with treated and untreated date seeds on In vitro gas production parameters, digestibility, rumen parameters and some blood parameters .

\section{MATERIAL AND METHODS}

The present study was carried out in 2017, at the Department of Animal Production, faculty of agriculture, Ain Shams University, Cairo, Egypt and the experiment of the farm animals occurred in the Animal Production research institute, Cairo, Egypt.Where the In vitro digestibility consumed $24 \mathrm{~h}$ but the incubation period was 1 month, while the In vivo digestibility was carried out through 21 day.

\section{Small scale silo}

Date seeds was sun dried to $90 \% \mathrm{DM}$ and crushed to $2-4 \mathrm{~cm}$ and mixed with water, molasses, urea $(2 \% \mathrm{w} / \mathrm{w})$, formic acid and acetic acid according to Abd El-Galil, (2006). The two strains of bacteria were subjected to one of the following treatments using 1.5 liters $\left(7.7 \times 10^{5}\right.$ viable anaerobes $/ \mathrm{kg}$ of wet silage) /ton:

UDS: untreated date seeds (control). T1DS: date seeds treated with Acetobacter xylinum. T2DS: date seeds treated with Thermonospora fusca. Treated samples were pressed in plastic bags for farm and used after incubated for 6 weeks

\section{Bacterial cultures}

Two strains of cellulolytic bacteria were isolated from rumen fluid of sheep and were grown as pure cultural. Rumen fluid of sheep was collected by a stomach tube. The separated strains were Acetobacter xylinum and Thermonospora fusca. The two isolated species were purified using the pourplate technique according to A.T.C.C. (1992).

\section{Chemical composition}

The proximate analysis of concentrate feed mixture (CFM), control, treated date seeds and rice straw were determined according to A.O.A.C. (1995). The chemical composition were used to determine dry matter (DM), crude protein (CP), crude fiber (CF), ether extract (EE) and ash. The nitrogen free extract (NFE) was obtained by the difference. The chemical composition of feed in- 

with bacteria

gredients and Invitro gas production rations are shown in Table (1) and Table (2).

\section{Cell wall constituents analysis}

CFM, control, treated date seeds and rice straw Breston (1979) to determine neutral detergent fiber (NDF), Acid detergent fiber (ADF) and acid detergent lignin (ADL). Hemicellulose, cellulose and lignin were determined by difference.

\section{In vitro Degradability}

Dry matter degradability (\% DMD) was calculated as the difference between the sample DM content before and after $48 \mathrm{~h}$ incubation / sample DM content * 100.

Also, degradability of NDF, ADF, cellulose and hemicellulose were calculated as difference between the content in the sample before and after incubation / content in the sample before incubation * 100 .

$$
(\% \mathrm{DMD})=\frac{D M \text { before }- \text { DM after }}{D M \text { before }} * 100
$$

\section{In vitro gas production}

After $24 \mathrm{~h}$ of samples incubation, the total gas production (GP) was estimated by the displacement of syringe piston, which was connected to the serum flasks. The gas produced due to fermentation of substrate was calculated by subtracting gas produced in blank vessels (without substrate) from were analyzed according to Van Soest and

total gas produced in the vessels containing substrate.

Table 1. Chemical composition of feed ingredients.

\begin{tabular}{|c|c|c|c|c|c|}
\hline Item & $\begin{array}{l}\text { Rice } \\
\text { Straw }\end{array}$ & $\begin{array}{l}\text { Con- } \\
\text { cen- } \\
\text { trate }\end{array}$ & $\begin{array}{c}\text { UDS } \\
\text { Untreated } \\
\text { Date Seed }\end{array}$ & $\begin{array}{c}\text { T1DS } \\
\text { T1(Aceto) } \\
\text { Date } \\
\text { Seed }\end{array}$ & $\begin{array}{c}\text { T2DS } \\
\text { T } 2 \\
\text { (Thermo) } \\
\text { Date } \\
\text { Seed }\end{array}$ \\
\hline \multicolumn{6}{|c|}{ On DM basis: } \\
\hline OM & 88.26 & 94.73 & 92.98 & 93.13 & 93.62 \\
\hline CP & 2.66 & 16.03 & 7.50 & 12.48 & 14.91 \\
\hline EE & 2.21 & 4.77 & 3.80 & 4.87 & 4.98 \\
\hline CF & 42.13 & 20.67 & 16.78 & 13.53 & 12.91 \\
\hline $\begin{array}{l}\text { NFE } \\
\text { Ash }\end{array}$ & $\begin{array}{l}36.24 \\
11.74\end{array}$ & $\begin{array}{c}54.10 \\
5.27\end{array}$ & $\begin{array}{c}64.90 \\
7.02\end{array}$ & $\begin{array}{c}62.25 \\
6.87\end{array}$ & $\begin{array}{c}60.82 \\
6.38\end{array}$ \\
\hline \multicolumn{6}{|c|}{ Cell wall constituents } \\
\hline NDF & 68.74 & 65.66 & 77.36 & 45.19 & 47.19 \\
\hline $\begin{array}{l}\text { ADF } \\
\text { hemicel- }\end{array}$ & 50.83 & 53.94 & 39.58 & 38.24 & 36.79 \\
\hline lulose & 17.91 & 15.24 & 37.78 & 6.95 & 10.40 \\
\hline cellulose & 42.40 & 3.98 & 33.78 & 29.84 & 25.99 \\
\hline \multicolumn{6}{|c|}{$\begin{array}{l}\text { Where: Concentrate mixture contained Soya bean } 17 \% \text {, energy } \\
\text { source } 50 \% \text {, wheat bran } 30 \% \text {, Mineral and vitamins } 1.5 \% \text {, lime } \\
\text { stone } 1.5 \% \text {. DM: dry matter OM: organic matter CP : crude } \\
\text { protein CF: crude fiber EE :ether extract NFE : nitrogen free } \\
\text { extract } \\
\text { Where : Control: } 40 \% \text { rice straw }+60 \% \text { concentrate. UDS: un- } \\
\text { treated date seed.T1DS: treated } 1 \text { (Acetobacter xylinum) date } \\
\text { seed } \\
\text { T2DS: treated } 2 \text { (Thermonospora fusca) date seed }\end{array}$} \\
\hline
\end{tabular}

Table 2. Chemical composition of rations used in In vitro gas production

\begin{tabular}{|c|c|c|c|c|c|c|c|c|c|c|c|c|c|}
\hline \multirow{2}{*}{ item } & Control & \multicolumn{10}{|c|}{ Untreated Date Seeds(UDS) } & \multicolumn{1}{c|}{ Treated(1) Date Seeds(T1DS) } & \multicolumn{1}{|c|}{ Treated(2) Date Seeds (T2DS) } \\
\cline { 2 - 12 } & $0 \%$ & $25 \%$ & $50 \%$ & $75 \%$ & $100 \%$ & $25 \%$ & $50 \%$ & $75 \%$ & $100 \%$ & $25 \%$ & $50 \%$ & $75 \%$ & $100 \%$ \\
\hline DM & 88.78 & 89.27 & 89.76 & 90.24 & 90.73 & 89.19 & 89.60 & 90.01 & 90.42 & 89.07 & 89.36 & 89.65 & 89.95 \\
\hline \multicolumn{10}{|c|}{ DM basis } \\
\hline OM & 92.14 & 91.87 & 91.61 & 91.35 & 91.09 & 91.90 & 91.66 & 91.42 & 91.18 & 91.97 & 91.80 & 91.64 & 91.47 \\
CP & 10.68 & 9.40 & 8.12 & 6.84 & 5.56 & 10.14 & 9.61 & 9.08 & 8.55 & 10.51 & 10.34 & 10.17 & 10.01 \\
EE & 3.74 & 3.60 & 3.45 & 3.30 & 3.16 & 3.76 & 3.77 & 3.79 & 3.80 & 3.77 & 3.80 & 3.84 & 3.87 \\
CF & 29.25 & 28.67 & 28.08 & 27.50 & 26.92 & 28.18 & 27.11 & 26.04 & 24.97 & 28.09 & 26.92 & 25.76 & 24.59 \\
NFE & 46.95 & 48.57 & 50.19 & 51.81 & 53.43 & 48.17 & 49.40 & 50.62 & 51.84 & 47.96 & 48.97 & 49.98 & 50.98 \\
Ash & 7.85 & 8.12 & 8.38 & 8.64 & 8.90 & 8.09 & 8.33 & 8.57 & 8.81 & 8.02 & 8.19 & 8.35 & 8.52 \\
\hline \multicolumn{10}{|c|}{ Cell wall constituents } \\
\hline NDF & 66.89 & 68.64 & 70.40 & 72.15 & 73.91 & 63.82 & 60.75 & 57.68 & 54.61 & 64.12 & 61.35 & 58.58 & 55.81 \\
ADF & 52.69 & 50.12 & 47.55 & 44.97 & 42.40 & 50.34 & 47.98 & 45.63 & 43.27 & 50.54 & 48.38 & 46.23 & 44.08 \\
Hemi & 16.30 & 20.10 & 23.90 & 27.70 & 31.50 & 15.06 & 13.82 & 12.57 & 11.33 & 15.16 & 14.01 & 12.87 & 11.73 \\
cell & 19.34 & 22.64 & 25.95 & 29.25 & 32.55 & 23.22 & 27.10 & 30.98 & 34.86 & 23.81 & 28.28 & 32.75 & 37.22 \\
\hline
\end{tabular}

Where : Control: $40 \%$ rice straw $+60 \%$ concentrate . UDS: untreated date seed

T1DS: treated 1(Acetobacter xylinum) date seed. T2DS: treated 2 (Thermonospora fusca) date seed 


\section{Calculation}

Metabolizable energy (ME, Mcal/kg DM), In vitro organic matter digestibility (OMD, g/kg OM) were estimated according to (Menke and Steingass, 1988), short chain fatty acid (SCFA) concentrations were calculated according to Getachew et al (2002), microbial biomass production (MCP) and efficiency of microbial biomass production (EMP) were calculated according to Blummel et al (1997) as:

- ME $(\mathrm{mJ} / \mathrm{kg} \mathrm{DM})=2.20+0.136 \mathrm{GP}+0.057$

CP (\%).

- $\mathrm{OMD}=14.88+0.889 \mathrm{GP}+4.5 \mathrm{CP}(\%)+$ 0.0651 ash (\%).

- SCFA $(\mathrm{mmol} / 200 \mathrm{mg} \mathrm{DM})=-0.00425+$ 0.0222 * GP

- $\mathrm{MCP}(\mathrm{mg} / \mathrm{g} \mathrm{DM})=\mathrm{mg} \mathrm{dDM}-\mathrm{GP}^{\star} 2.2$.

- $E M P=(m g$ DMD- GP*2.2 ))/mg DMD.

- where : GP is net gas production in $\mathrm{mL}$ from $200 \mathrm{mg}$ of dry sample after $24 \mathrm{~h}$ of incubation, $2.2 \mathrm{mg} / \mathrm{mL}$ is a stoichiometric factor that expresses $\mathrm{mg}$ of $\mathrm{C}, \mathrm{H}$, and $\mathrm{O}$ required for the SCFA gas associated with production of $1 \mathrm{~mL}$ of gas.

After 24 hrs of incubation, the filtrated rumen liquor for each sample was subjected for further investigation. The $\mathrm{pH}$ of rumen fluid was measured $\mathrm{pH}$ meter and quantitative analysis of ammonia concentration was carried out by Nesler method modified by Szumacher-Strabel et al (2002) and total volatile fatty acids (TVFA's) was analyzed according to Barnett and Reid (1956).

\section{Animals and Metabolism trials}

Nine Rahmany mature rams were randomly chosen and divide into three experimental groups, three animals in each group. All animals were reared under the same environmental condition. Each group of animals was fed the following rations:

R1 : $60 \%$ cocentrate : $40 \%$ rice straw. R2: 25 $\%$ cocentrate: $25 \%$ date seed untreated $: 50 \%$ rice straw . R3: $25 \%$ cocentrate : $25 \%$ date seed treatment 2 (Thermonospora fusca): $25 \%$ rice straw

Three digestion trials were carried out to determine nutrients digestibility, feeding values and nitrogen balance of tested ration by using metabolic cages. Three rams were used in each. At the end of the digestibility trial samples of rumen fluids were collected from each animal at zero, 3 and 6 hrs post feeding by stomach tube. Animals were fed at maintenance requirements using the allowances of NRC (1985). The chemical composition of experimental rations are shown in Table (3).

The rams were fed individually in metabolic cages. Water was available free. The trial extend- ed for 21 days, adaptation period lasted for 14 days and collection period lasted for 7 days. Feces and urine were collected quantitatively daily during the collection period as described by Mynard et al (1979). Solution of $10 \% \mathrm{H}_{2} \mathrm{So}_{4}$ was added to the representative feces samples before drying in oven at $60{ }^{\circ} \mathrm{C}$ for $24 \mathrm{hrs}$.

Table 3. Chemical composition of experimental Rations

\begin{tabular}{|l|c|c|c|}
\hline \multicolumn{1}{|c|}{ Item } & R1 & R 2 & R 3 \\
\hline DM & 87.78 & 89.76 & 89.36 \\
\hline DM basis & & & \\
\hline OM & 92.14 & 91.61 & 91.80 \\
CP & 10.68 & 8.12 & 10.34 \\
EE & 3.74 & 3.45 & 3.80 \\
CF & 29.25 & 28.08 & 26.92 \\
NFE & 46.95 & 50.19 & 48.97 \\
Ash & 7.85 & 8.38 & 8.19 \\
\hline Cell wall constituents & & \\
\hline NDF & 66.89 & 70.40 & 61.35 \\
ADF & 52.69 & 47.55 & 48.38 \\
Hemicell & 16.30 & 23.90 & 14.01 \\
Cell & 19.34 & 25.95 & 28.28 \\
\hline
\end{tabular}

Where: Concentrate mixture contained Soya bean $17 \%$, energy source $50 \%$, wheat bran $30 \%$, Mineral and vitamins $1.5 \%$, lime stone $1.5 \%$.

R1 : $50 \%$ cocentrate : $50 \%$ rice straw

R2: $25 \%$ concentrate: $25 \%$ date seed untreated : $50 \%$ rice straw

R3: $25 \%$ concentrate: $25 \%$ date seed treatment 2 (Thermonospora fusca): $25 \%$ or $50 \%$ rice straw.

Dried samples were ground and kept for chemical analysis. Add $50 \mathrm{ml}$ of diluted Sulfuric acid $(10 \%)$ was in urine collecting containers each day. A representative samples (10\%) of urine volume was stored for nitrogen determination.

\section{Analytical methods}

Samples of feedstuffs and feces were taken and air dried at $55 \mathrm{C}^{\circ}$ for 48 hour in forced air oven up to about $10-12 \%$ moisture, then kept to subsequent analysis. Dried samples were ground through a Wiley Mill fitted with a $1 \mathrm{~mm}$ screen and chemically analyzed according to A.O.A.C (1995) while NFE content was calculated by difference. Urine samples were subjected to $\mathrm{N}$ determination according to A.O.A.C (1995). Ruminal pH was immediately determined with a digital $\mathrm{pH}$ meter $\mathrm{pH}$ 

with bacteria

ep $\AA$, pocket-sized $\mathrm{pH}$ meter Hana instruments, Italy) before rumen liquor was stored. Concentration of NH3-N was immediately determined using micro-diffusion method of Conway (1963). Frozen rumen liquor samples were analyzed for total volatile fatty acids (TVF's) by steam distillation according to Warner (1964). Blood serum was analyzed using special kits for urea (Patton and Crouch, 1977), total protein (Henry, 1964) and Creatinine (Henry, 1974).

\section{Statistical analysis}

The data of In vitro gas production, dry matter, organic matter, hemicellulose, cellulose digestibility , and In vitro dry matter, organic matter, hemicellulose, cellulose degradability, digestion coefficient, rumen and blood parameters were statistically analyzed according to statistical analysis system User's Guide, (SAS, 1998). Separation among means was carried out by using Duncan Multiple test (Duncan, 1955). The following model was used:

$$
Y_{i j}=\mu+S_{i}+\alpha_{i j}
$$

Where: $Y_{i j}=$ the observation of the model, $\mu=$ General mean common element to all observation, $\mathrm{Si}=$ the effect of the treatment $(i=1 \ldots 3)$, and $\alpha_{i j}=$ the effect of experimental error.

\section{RESULTS AND DISCUSSION}

In vitro DM, OM, Cellulose and Hemicellulose digestibility

A significant high $(\mathrm{P}<0.05) \mathrm{DM}, \mathrm{OM}$ and NDF degradability after 24 hours was recorded for ration contain untreated date seeds $(25 \%)$ while the highest value was recorded for ration control without date seed (Table 4). The present results pointed to no significant effect for rations contain treated date seed with bacteria (all different level of replacement ) on DM and OM degradability which the high values were in control and untreated date seed $(25 \%)$.

While the rations content $25 \%$ treated date seed with bacteria (T1 and T2) replacement were high values compared any different level replacement concentrate above $25 \%$ decrease in OM degradability (Table 4). On the other hand the ration contain $25 \%$ treated untreated and treated with bacteria had significant values on NDF, ADF and hemicellulose degradability after 24 hours, especially treatment 2 (Thermonospora fusca) of date seed. Moreover rations contain untreated date seed $50 \%$ higher than control (without date seed) for cellulose degradation while rations treated date seed with bacteria T2 (Thermonospora fusca ) 50 and $25 \%$ then date seed treated (T1) with Acetobacter xylinum 25\% replacement concentration . In addition, ration with ascending level of untreated and treated date seed had more effect on total gas production (GP). This positive response for bacterial treatment (T1 or T2) on NDF, ADF, hemicellulose and cellulose degradability may be attributed to that effect of cellulolytic bacteria resulted in increase digestibility (Table 4) consequently increase cellulolytic enzyme activity.

Elghandour et al (2014) reported an improved fibers fractions degradability as a result of increased cellulolytic digester species : Fibrobacter succinogenes, Ruminococcus flavifaciens and Selenomonas ruminantium. Also Colombatto et al (2007) stated that fibrolytic enzymes enhanced the fermentation of cellulose and xylan by a combination of pre- and post- incubation effects. The gas production, form any substrate, depends mainly on nutrient availability for rumen microorganisms (Elghandour et al 2014).

Table 4. In vitro gas production (gas production $400 \mathrm{mg} \mathrm{DM} \mathrm{ml} /$ ) and invitro degradability of rations contained date seed untreated or treated with bacteria after 24 hours on DM basis

\begin{tabular}{|c|c|c|c|c|c|c|c|c|c|c|c|c|c|c|}
\hline \multirow{2}{*}{ Item } & \multirow{2}{*}{$\begin{array}{c}\text { control } \\
0\end{array}$} & \multicolumn{4}{|c|}{ Untreated Date Seeds(UDS) } & \multicolumn{4}{|c|}{ Treated(1) Date Seeds(T1DS) } & \multicolumn{4}{|c|}{ Treated(2) Date Seeds (T2DS) } & \multirow{2}{*}{$\begin{array}{c}\text { SE } \\
\pm\end{array}$} \\
\hline & & $25 \%$ & $50 \%$ & $75 \%$ & $100 \%$ & $25 \%$ & $50 \%$ & $75 \%$ & $100 \%$ & $25 \%$ & $50 \%$ & $75 \%$ & $100 \%$ & \\
\hline & 44.00 & & $33.33^{c}$ & $35.33^{b}$ & $30.00^{d}$ & $42.66^{a}$ & $35.66^{b}$ & $32.00^{c}$ & $20.33^{e}$ & $38.33^{b}$ & $32.33^{c}$ & $28.66^{d}$ & $20.66^{\mathrm{e}}$ & 0.85 \\
\hline & $47.00^{a}$ & $41.12^{b}$ & $32.91^{c}$ & $34.55^{c}$ & $29.51^{d}$ & $35.48^{c}$ & $34.22^{c}$ & $25.11^{d}$ & $20.80^{\mathrm{e}}$ & $36.21^{c}$ & $27.18^{d}$ & $26.03^{d}$ & $16.43^{e}$ & 0.70 \\
\hline DO & $37.80^{\mathrm{a}}$ & $38.08^{a}$ & $32.16^{b}$ & $32.97^{b}$ & $30.32^{c}$ & $37.01^{\mathrm{a}}$ & $33.35^{b}$ & $31.53^{b}$ & $25.79^{d}$ & $34.85^{b}$ & $31.70^{c}$ & $30.00^{c}$ & $26.06^{d}$ & 0.27 \\
\hline DN & $49.51^{a}$ & $46.34^{\mathrm{a}}$ & $34.69^{b}$ & $37.33^{b}$ & $30.17^{c}$ & $38.37^{b}$ & $26.22^{d}$ & $10.86^{\mathrm{e}}$ & 0 & $38.82^{b}$ & $22.99^{d}$ & $7.73^{\mathrm{e}}$ & 0 & 0.95 \\
\hline DAD & $60.78^{a}$ & $50.60^{\mathrm{b}}$ & $35.42^{d}$ & $25.80^{c}$ & $10.31^{e}$ & $43.96^{c}$ & $33.54^{d}$ & $16.12^{\mathrm{e}}$ & 0 & $46.62^{c}$ & $30.93^{\mathrm{d}}$ & $16.77^{\mathrm{e}}$ & 0 & 1.65 \\
\hline DHer & $48.19^{b}$ & $54.58^{\mathrm{a}}$ & $52.01^{\mathrm{a}}$ & $51.32^{\mathrm{a}}$ & $55.96^{\mathrm{a}}$ & $47.55^{b}$ & $45.87^{b}$ & $44.45^{b}$ & $47.01^{b}$ & $52.50^{\mathrm{a}}$ & $40.50^{c}$ & $44.70^{c}$ & $4.99^{d}$ & 0.99 \\
\hline Dcellul,\% & $42.91^{c}$ & $43.19^{c}$ & $45.61^{c}$ & $41.35^{c}$ & $40.05^{c}$ & $40.87^{c}$ & $42.82^{c}$ & $55.36^{\mathrm{b}}$ & $54.05^{\mathrm{b}}$ & $56.72^{\mathrm{b}}$ & $61.37^{\mathrm{a}}$ & $44.79^{c}$ & $3.21^{d}$ & 3.21 \\
\hline
\end{tabular}

a,b,c,d and e : means in the same rows with different superscripts differed significantly at $(p<0.05)$.

Where :

Control: $40 \%$ rice straw $+60 \%$ concentrate. UDS: untreated date seed.

T1DS: treated 1(Acetobacter xylinum) date seed. T2DS: treated 2 (Thermonospora fusca) date seed . 


\section{Fermentation parameters}

In the experimental ration with ascending level of untreated and treated date seed had not significant effect on $\mathrm{pH}$ value while more effect ammonia, TVFA's , MP, EMP and metabolizable energy $\mathrm{ME}$ (Mcal/ g) (Table 5). Ammonia concentration $(\mathrm{mg} / 100 \mathrm{ml})$ and total volatile fatty acids (meq /100 $\mathrm{ml}$ ) were recorded $(P>0.05)$ increase as a result of supplemeating ration with date seed at $25 \%$ of untreated and treated compared to other levels. These results may be due to added treated date seed affect on bacteria activity which increased growth and activity ruminal bacteria and causes increase protein degradation (Table 5). Ruminant rations with untreated and treated date seed at $25 \%$ resulted in increase microbial mass protein (MP) and efficiency of microbial mass (EMP) compared to $100 \%$ of replacement in all rations. Several studies have suggested that during fermenta- tion due to increasing $\mathrm{pH}$ and lactate utilization making $\mathrm{pH}$ relatively more stable and meet the needs of rumen microbes to perform its activity (Elghandour et al 2014).

Fermentation of dietary carbohydrates to acetate, propionate and butyrate produces gases in the rumen. However, in the current study, standard ration had the same fiber fractions content in different additives. So, it is well clear that the increased gas production (GP) was a result of increased adding of nanocobalt to ration. It is well known that microorganisms has the ability to increase ammonia production in the rumen (Hristov et al 2013) by increasing protein degradation and increased the overall $\mathrm{N}$ excretion by the animal. In these study, the low level of date seed used (25\%) improved degradability, gas production and kinetics of fermentation (SCFA, $\mathrm{NH}_{3}$ and MP) than the high level of date seed.

Table 5. Rumen parameters of rations contain date stone untreated or treated with bacteria

\begin{tabular}{|c|c|c|c|c|c|c|c|c|c|c|c|c|c|c|}
\hline \multirow{2}{*}{ Item } & \multirow{2}{*}{$\begin{array}{c}\text { control } \\
0 \\
\end{array}$} & \multicolumn{4}{|c|}{ Untreated Date Seeds(UDS) } & \multicolumn{4}{|c|}{ Treated (1) Date Seeds (T1DS) } & \multicolumn{4}{|c|}{ Treated (2) Date Seeds (T2DS) } & \multirow{2}{*}{$\begin{array}{c}\text { SE } \\
\pm \\
\end{array}$} \\
\hline & & $25 \%$ & $50 \%$ & $75 \%$ & $100 \%$ & $25 \%$ & $50 \%$ & $75 \%$ & $100 \%$ & $25 \%$ & $50 \%$ & $75 \%$ & $100 \%$ & \\
\hline Gas production & & & & & & & & & & & & & & \\
\hline $\begin{array}{l}\text { GP24(Total GP) } \\
\text { Rumen parameter }\end{array}$ & $44.00^{\mathrm{a}}$ & $45.00^{\mathrm{a}}$ & $33.33^{\mathrm{c}}$ & $35.33^{b}$ & $30.00^{d}$ & $42.66^{a}$ & $35.66^{\mathrm{b}}$ & $32.00^{\mathrm{C}}$ & $20.33^{e}$ & $38.33^{\mathrm{b}}$ & $32.33^{c}$ & $28.66^{d}$ & $20.66^{e}$ & 0.85 \\
\hline $\mathrm{pH}$ & 6.64 & 6.54 & 6.54 & 6.50 & 6.53 & 6.56 & 6.61 & 6.60 & 6.53 & 6.53 & 6.64 & 6.60 & 6.01 & 0.01 \\
\hline NH3 & $12.87^{\mathrm{c}}$ & $8.81^{d}$ & $7.88^{d}$ & $9.22^{d}$ & $10.37^{\mathrm{c}}$ & $23.32^{\mathrm{a}}$ & $18.61^{b}$ & $17.95^{\mathrm{b}}$ & $11.99^{\circ}$ & $16.10^{b}$ & $10.87^{\mathrm{c}}$ & $11.46^{\mathrm{c}}$ & $2.69^{e}$ & 0.69 \\
\hline TVFA's & $7.09^{\mathrm{a}}$ & $6.89^{\mathrm{b}}$ & $6.80^{\mathrm{b}}$ & $6.16^{\mathrm{c}}$ & $6.94^{\mathrm{b}}$ & $6.83^{\mathrm{b}}$ & $6.14^{c}$ & $7.11^{\mathrm{a}}$ & $7.89^{\mathrm{a}}$ & $7.23^{\mathrm{a}}$ & $6.34^{\mathrm{c}}$ & $6.39^{c}$ & $4.15^{d}$ & 0.15 \\
\hline MP & $198.66^{a}$ & $135.80^{\mathrm{b}}$ & $126.54^{\mathrm{c}}$ & $132.37^{b}$ & $114.35^{\mathrm{d}}$ & $125.66^{c}$ & $93.05^{\mathrm{e}}$ & $57.01^{\mathrm{f}}$ & $84.84^{e}$ & $127.22^{\mathrm{C}}$ & $85.67^{\mathrm{e}}$ & $75.16^{\mathrm{e}}$ & $38.34^{f}$ & 3.33 \\
\hline EMP & $42.16^{a}$ & $38.75^{\mathrm{a}}$ & $32.91^{\mathrm{b}}$ & $35.89^{b}$ & $36.68^{b}$ & $35.90^{\mathrm{b}}$ & $26.32^{c}$ & $22.69^{d}$ & $21.13^{d}$ & $35.09^{b}$ & $27.06^{\mathrm{c}}$ & $32.80^{b}$ & $22.61^{d}$ & 0.86 \\
\hline SCFA & $2.73^{a}$ & $2.77^{\mathrm{a}}$ & $2.04^{b}$ & $2.14^{b}$ & $1.82^{c}$ & $2.63^{a}$ & $2.18^{b}$ & $1.95^{c}$ & $1.23^{d}$ & $2.36^{a}$ & $1.98^{c}$ & $1.75^{c}$ & $1.26^{d}$ & 0.04 \\
\hline M. E & $2.78^{\mathrm{a}}$ & $2.61^{\mathrm{a}}$ & $2.23^{\mathrm{a}}$ & $2.08^{b}$ & $1.81^{\mathrm{c}}$ & $2.68^{a}$ & $2.47^{\mathrm{a}}$ & $2.33^{a}$ & $2.05^{b}$ & $2.65^{\mathrm{a}}$ & $2.51^{\mathrm{a}}$ & $2.42^{\mathrm{a}}$ & $2.26^{\mathrm{a}}$ & 0.01 \\
\hline
\end{tabular}

a,b,c,d,e and $f$ :means in the same rows with different superscripts differed significantly at ( $\mathrm{p}<0.05)$. MP:microbial protein (mg/100 ml rumen liqour) - EMP: efficiency of microbial protein - SCFA: short chain fatty acid $(\mu \mathrm{m})$.

M E : metabolic energy (Mcal/g DM ). Where : Control: $40 \%$ rice straw $+60 \%$ concentrate. UDS: untreated date seed. T1DS: treated 1 (Acetobacter xylinum) date seed. T2DS: treated 2 (Thermonospora fusca) date seed

Improving ME, MP and GP(24) were observed with the ration of low level than those other's. Rations with high protein content provide ruminal microflora with the essential nutrients for its activity. The highly activity reflected on higher GP, higher microbial protein synthesis, and higher degradability.

\section{Digestability and degradability of In vitro gas production}

Gas production per gram DM, OM, NDF, ADF, Hemicellulose and Cellulose after 24 hours incubation showed in Table (6). Potential gas production was significantly affected by replacement concentrate with treated date seed which significant de- crease in gas production per gram DM, OM, NDF, ADF, cellulose and hemicellulose were observed for rations with all level of date seed untreated and treated 1 ecsept ration contain $25 \%$. On the other hand, the ration contain treated date seed (2) resulted in numerically increase in gas production per gram DM, OM, NDF and ADF, ecsept hemicellulose and cellulose. Siegel (1991) suggested that gas production from cereal straws and from different classes of feeds incubated In vitro in buffered rumen fluid was closely related to the production of short chain fatty acid (SCFA) which was based on carbohydrate fermentation. Bakker et al (1995) reported a close association between SCFA and gas production In vitro studies, suggests a potential to make energy available to the ruminants. 

with bacteria

After 24 hours incubation gas production degradability dry organic matter, NDF, ADF, cellulose and hemicellulose of $100 \%$ date seed untreated and treated bacteria (T1 and $\mathrm{T} 2$ ) were the lowest values compared any rations, but notes that the value of rations content treated (T1 and $\mathrm{T} 2$ ) date seed $25 \%$ were the highest values compared ration control without date seed. The results implying that increase growth of cellulolytic bacteria increase fermentation of cellulose and improve degradability of standard ration in the experiment. A higher potential gas production can contribute significantly to energy supply via short chain fatty acid production (Remesy et al 1995). Digestibility has been reported to be synonymous to In vitro gas production, with a high positive correlation obtained between gas production and dry matter digestibility (Datt and Singh, 1995). For gas volume and In vitro gas production characteristics, Lina et al (2009) suggested that gas volume at $24 \mathrm{~h}$ after incubation is an indirect relationship with metabo- lisable energy in feedstuffs. Gas production can be considered as an indicator of carbohydrates degradation. Lina et al (2009) and Rajendran (2013) suggested that gas volume is a good parameter from which to predict digestibility, fermentation end product and microbial protein synthesis of the substrate by rumen microbes in the In vitro studies. Gas production is basically the result of fermentation of carbohydrates to acetate, propionate and butyrate Sahoo (2014 a) and substantial changes in carbohydrates fractions were reflected by total gas produced (Te -Hsing et al 2007).

Gas production from protein fermentation is relatively small as compared to carbohydrate fermentation, while contribution of fat to gas production is negligible, Sahoo (2014 b). Mathematical descriptions of gas production profiles allow analysis of data evaluation of substrates and media related differences and fermentability of soluble and slowly fermentable components of feeds (Newman et al 2009).

Table 6. In vitro gas production digestibility ( $\mathrm{ml} / 1 \mathrm{~g} \mathrm{DM})$ and degradability $(\mathrm{g} / \mathrm{kg} \mathrm{DM}$ ) of rations contain date stone untreated or treated with bacteria

\begin{tabular}{|c|c|c|c|c|c|c|c|c|c|c|c|c|c|c|}
\hline \multirow{2}{*}{ Item } & \multirow{2}{*}{$\begin{array}{c}\text { Control } \\
0\end{array}$} & \multicolumn{4}{|c|}{ Untreated Date Seeds (UDS) } & \multicolumn{4}{|c|}{ Treated (1) Date Seeds (T1DS) } & \multicolumn{4}{|c|}{ Treated (2) Date Seeds (T2DS) } & \multirow{2}{*}{$\begin{array}{l}\text { SE } \\
\pm\end{array}$} \\
\hline & & $25 \%$ & $50 \%$ & $75 \%$ & $100 \%$ & $25 \%$ & $50 \%$ & $75 \%$ & $100 \%$ & $25 \%$ & $50 \%$ & $75 \%$ & $100 \%$ & \\
\hline \multicolumn{15}{|c|}{ Gas production digestibility 24 hours ( $\mathrm{ml} / 1 \mathrm{~g} \mathrm{DM}$ ) } \\
\hline GPDM & $123.36^{\mathrm{a}}$ & $125.17^{\mathrm{a}}$ & $92.10^{\mathrm{c}}$ & $96.90^{\mathrm{c}}$ & $82.18^{\mathrm{d}}$ & $118.97^{b}$ & $98.43^{\mathrm{c}}$ & $88.22^{c}$ & $55.99^{\mathrm{e}}$ & $136.76^{\mathrm{a}}$ & $89.41^{\mathrm{c}}$ & $79.40^{d}$ & $57.26^{\mathrm{e}}$ & 2.16 \\
\hline GPOM & $133.88^{\mathrm{b}}$ & $120.24^{\mathrm{C}}$ & $100.53^{d}$ & $106.07^{d}$ & $61.41^{\mathrm{t}}$ & $136.46^{b}$ & $107.37^{d}$ & $100.49^{c}$ & $90.22^{\mathrm{e}}$ & $146.08^{\mathrm{a}}$ & $116.85^{c}$ & $102.38^{d}$ & $96.65^{\mathrm{e}}$ & 2.29 \\
\hline GPNDF & $163.74^{\mathrm{b}}$ & $162.77^{\mathrm{b}}$ & $117.39^{\mathrm{e}}$ & $121.24^{\mathrm{e}}$ & $100.88^{f}$ & $166.39^{\mathrm{b}}$ & $145.10^{\mathrm{C}}$ & $137.58^{\mathrm{C}}$ & 0 & $184.38^{\mathrm{a}}$ & $130.13^{d}$ & $121.51^{\mathrm{e}}$ & 0 & 6.12 \\
\hline GPADF & $207.89^{a}$ & $223.00^{\mathrm{a}}$ & $173.98^{\mathrm{c}}$ & $194.20^{b}$ & $175.89^{c}$ & $188.24^{b}$ & $183.71^{b}$ & $173.92^{\mathrm{c}}$ & 0 & $210.93^{a}$ & $165.01^{d}$ & $153.93^{\mathrm{e}}$ & 0 & 11.70 \\
\hline GPhemi & $190.14^{\mathrm{a}}$ & $148.16^{b}$ & $154.19^{b}$ & $134.59^{c}$ & $120.93^{d}$ & $200.36^{\mathrm{a}}$ & $119.16^{d}$ & $100.65^{d}$ & $92.08^{e}$ & $137.40^{c}$ & $100.61^{d}$ & $95.48^{\mathrm{e}}$ & $20.13^{f}$ & 31.33 \\
\hline GPcell & $195.11^{\mathrm{b}}$ & $177.88^{\mathrm{C}}$ & $100.00^{\mathrm{e}}$ & $81.97^{f}$ & $72.23^{f}$ & $235.64^{\mathrm{a}}$ & $113.79^{d}$ & $104.39^{\mathrm{e}}$ & $81.37^{f}$ & $160.40^{\circ}$ & $122.75^{d}$ & $81.50^{f}$ & $14.40^{f}$ & 17.69 \\
\hline \multicolumn{15}{|c|}{ Gas production degradability 24 hours (g/kg DM) } \\
\hline GPdDM & $374.72^{\mathrm{a}}$ & $587.41^{\mathrm{b}}$ & $518.41^{\mathrm{C}}$ & $500.02^{\mathrm{C}}$ & $477.10^{d}$ & $652.30^{\mathrm{a}}$ & $575.02^{b}$ & $551.93^{\mathrm{b}}$ & $494.54^{d}$ & $690.54^{a}$ & $650.03^{\mathrm{a}}$ & $513.14^{\mathrm{c}}$ & $477.91^{d}$ & 2.41 \\
\hline GPdOM & $943.76^{\mathrm{b}}$ & $960.88^{b}$ & $940.37^{b}$ & $905.94^{b}$ & $408.63^{b}$ & $969.89^{b}$ & $986.98^{b}$ & $951.18^{\mathrm{b}}$ & $416.17^{e}$ & $1131.84^{\mathrm{a}}$ & $908.56^{\mathrm{b}}$ & $803.31^{\mathrm{c}}$ & $589.31^{d}$ & 5.32 \\
\hline GPdNDF & $331.42^{d}$ & $351.31^{c}$ & $338.03^{d}$ & $334.39^{d}$ & $338.92^{d}$ & $433.83^{b}$ & $556.71^{a}$ & $409.03^{b}$ & 0 & $576.41^{\mathrm{a}}$ & $384.41^{\mathrm{C}}$ & $338.78^{d}$ & 0 & 14.04 \\
\hline GPdADF & $341.93^{\mathrm{C}}$ & $440.87^{b}$ & $492.31^{\mathrm{b}}$ & $480.27^{b}$ & $160.24^{e}$ & $479.36^{b}$ & $548.88^{a}$ & $237.85^{d}$ & 0 & $564.47^{\mathrm{a}}$ & $403.32^{\mathrm{b}}$ & $139.39^{\mathrm{e}}$ & 0 & 15.53 \\
\hline GPdhemi & $373.79^{b}$ & $328.56^{\mathrm{b}}$ & $344.55^{b}$ & $228.98^{d}$ & $195.61^{\mathrm{e}}$ & $300.77^{c}$ & $166.64^{f}$ & $183.58^{\mathrm{e}}$ & $109.63^{f}$ & $450.67^{a}$ & $341.67^{b}$ & $194.78^{\mathrm{e}}$ & $75.18^{f}$ & 12.62 \\
\hline GPdcell & $391.15^{\mathrm{C}}$ & $344.71^{c}$ & $299.35^{d}$ & $420.37^{b}$ & $523.75^{a}$ & $411.18^{b}$ & $111.31^{\mathrm{e}}$ & $87.01^{f}$ & $74.41^{f}$ & $577.83^{a}$ & $441.83^{b}$ & $133.48^{\mathrm{e}}$ & $31.42^{f}$ & 10.22 \\
\hline
\end{tabular}

$a, b, c, d, e$ and $f$ :means in the same rows with different superscripts differed significantly at $(p<0.05)$.

Gas production ( $\mathrm{ml} / \mathrm{g} \mathrm{DM})$ and degradability of DM OM, NDF,ADF, hemicellulose and cellulose (g $/ \mathrm{kg} \mathrm{DM})$ after 24 hours incubation. Where: Control: $40 \%$ rice straw $+60 \%$ concentrate. UDS: untreated date seed. T1DS: treated 1 (Acetobacter xylinum) date seed. T2DS: treated 2 (Thermonospora fusca) date seed.

Although gas production is a nutritionally wasteful products (Ingale and Chaudhari, 2013), but provides useful basis from which ME, OMD and SCFA may be predicted (Yang and Sun, 2006). There was a positive correlation between metabolisable energy calculated from In vitro gas production together with $\mathrm{CP}$ and fat content with metabolisable energy value of conventional feeds measured In vivo (Kaiser et al 2014). The OMD differed significantly with other agricultural wastes. Iravani et al (2014) found a high precision in prediction of In vivo OMD. This group further used a correlative approach to predict the ME content of 
feed by In vitro gas production measurement and chemical constituents and concluded that the prediction of ME is more accurate when based on gas and chemical constituents only (Lina et al 2009). Other studies (Lina et al 2009 and Rajendran et al 2013) have also reported significant correlation between In vitro gas measurement and In vivo digestibility. KinfAemi et al (2009) showed that the In vitro gas production techniques can be used to assess the nutritive value of tropical agricultural wastes and to differentiate between their potential digestibility and metabolisable energy contents, also chemical composition and In vitro digestibility are very useful in estimation of OMD, SCFA and ME. Date-pits include high amount (14.4\%) of crude fibre and sodium hydroxide treatment of date-pits increased the rate of in-vitro digestibility by solubilizing some of the cell wall components, such as neutral detergent fibre (NDF), acid detergent fibre (ADF), hemicellulose, and cellulose. However, lignin content was not affected by sodium hydroxide treatment (Al-Yousef et al 1986).

\section{Digestion coefficient}

Data in (Table 7) indicated that experimental rations in metabolic trial control ration without date seed (R1), ration content $25 \%$ untreated date seed (R2) and ration content $25 \%$ treated date seed (R3) there were significantly $(P<0.05)$ increased in ration 3 (R3) for DM, OM, CP, EE, CF, ADF and cellulose digestibility as compared with control ration (R1) and ration $2(\mathrm{R} 2)$. The highest values digestibility were recorded with R3 treated with date seed Thermonospora fusca than R1 and R2 but the lowest values in ration 1 without date seed recorded in $\mathrm{OM}$ and cellulose digestibility. On the other side, the lowest values $(P<0.05)$ in ration 2 with untreated date seed recorded in CP,EE and CF digestibility. Data presented in Table (7) showed that no significant differences among animals fed rations $R 1$ and $R 2$ in $D M$ and ADF digestibility.

The differences were significant $(P<0.05)$ between control ration and other experimental rations. Furthermore, ration contain treated date seed (R3) had the highest values of DM, OM, CF and EE digestibility. It could be noticed that improving $\mathrm{CP}, \mathrm{CF}$ and cell wall costatuents (NDF, ADF, hemicellulose and cellulose) digestibility may be due to the increasing number of rumen cellulolytic bacteria (Gomez-Alarcon et al 1987) and increase in population (Newbold et al 1996) and lor activity of rumen cellulolytic bacteria (Dawson, 1993). The results were harmony with Beauchemin et al (2003) reported that adding exogenous fibrolytic enzymes to dairy cow and feedlot cattle diets can potentially cell wall digestion and the efficiency of feed utilization by ruminants. The nutritive values as TDN \% in Table (7) noticed that control ration without date seed had $(P<0.05)$ the lowest value while, the ration of $\mathrm{R} 2$ and $\mathrm{R} 3$ were recorded significantly $(P<0.05)$ the highest value of TDN.

Table 7. Effect of replacement concentrate with date seed untreated and treated on digestion coefficient in experimental ration

\begin{tabular}{|c|cccc|}
\hline Item & R1 & R 2 & R 3 & $\pm S E$ \\
\hline \multicolumn{5}{|c|}{ Digestibility coefficients, \% } \\
\hline DM & $63.60^{\mathrm{b}}$ & $63.40^{\mathrm{b}}$ & $75.55^{\mathrm{a}}$ & 1.12 \\
OM & $69.61^{\mathrm{c}}$ & $72.52^{\mathrm{b}}$ & $79.67^{\mathrm{a}}$ & 1.14 \\
CP & $40.00^{\mathrm{b}}$ & $36.86^{\mathrm{c}}$ & $72.93^{\mathrm{a}}$ & 0.94 \\
EE & $78.71^{\mathrm{b}}$ & $67.34^{\mathrm{c}}$ & $80.77^{\mathrm{a}}$ & 1.27 \\
CF & $57.55^{\mathrm{b}}$ & $54.75^{\mathrm{c}}$ & $74.25^{\mathrm{a}}$ & 0.94 \\
NFE & $82.62^{\mathrm{b}}$ & $87.45^{\mathrm{a}}$ & $83.26^{\mathrm{b}}$ & 0.89 \\
NDF & $80.43^{\mathrm{b}}$ & $85.20^{\mathrm{a}}$ & $86.37^{\mathrm{a}}$ & 0.76 \\
ADF & $66.39^{\mathrm{b}}$ & $65.52^{\mathrm{b}}$ & $77.48^{\mathrm{a}}$ & 0.68 \\
Hemicell & $91.29^{\mathrm{a}}$ & $85.31^{\mathrm{b}}$ & $80.43^{\mathrm{c}}$ & 0.38 \\
Cell & $78.18^{\mathrm{c}}$ & $86.44^{\mathrm{b}}$ & $90.19^{\mathrm{a}}$ & 0.22 \\
\hline \multicolumn{5}{|c}{ Nutritive values, $\%^{\mathrm{y}}$} \\
\hline TDN & $57.34^{\mathrm{c}}$ & $60.98^{\mathrm{b}}$ & $68.51^{\mathrm{a}}$ & 1.11 \\
N balance & $+2.16^{\mathrm{b}}$ & $+2.18^{\mathrm{b}}$ & $+3.76^{\mathrm{a}}$ & 0.43 \\
\hline
\end{tabular}

a,b and c:means in the same rows with different superscripts differed significantly at $(\mathrm{p}<0.05)$.

Where: R1: $50 \%$ cocentrate: $50 \%$ rice straw. R2: $25 \%$ cocentrate: $25 \%$ date seed untreated : $50 \%$ rice straw.

R3: $25 \%$ cocentrate: $25 \%$ treaded date seed 2 (Thermonospora fusca): $25 \%$ rice straw.

The N-balance values were significantly $(P<0.05)$ increased with rations of $R 3$ than those in other rations. This result was reflected to increase values of $\mathrm{CP}$ digestibility. These results are agreement with report of Abd El-Galil (2014) who recorded that DCP had higher significantly values with fibrozyme and with mixed fibrozyme and yeast (8.15 and $8.01 \%)$ and with yeast $(7.37 \%)$ than without supplement (6.59) These results means that biological additives or treatements effect on rations which may be increase the number of bacteria in the rumen and increase the digestibility and nutritive values in experimental diets.

Different schemes have been drawn up by different authors to draw together into a logical mode of action the various observations that have been made on microbial feed additives (Wallace and Newbold, 1992). These two observations are suggested to arise from a more active microbial population: the most effect of microbial feed additives is that they increase the viable count of anaerobic bacteria recovered from ruminal fluid. Increases of 

with bacteria

50 to $100 \%$ are common (Wallace and Newbold, 1993), but increases of more than 10 -fold compared with controls have been observed.

Cellulolytic bacterial numbers are increased (Wallace and Newbold, 1993) thus explaining in part the improvement in fiber breakdown and increased stability of the fermentation in animals receiving yeast and $A$. oryzae (Williams et al 1991). The estimated In vivo OM digestibility was in the $60-70 \%$ range calculated by Shem et al (1995) for bean straw, and are slightly higher than cereal straw OM digestibility (60\%). Nitrogen balance and metabolism was found to be improved due to the inclusion of $Y C$ in the diet of sheep. This may be due to the increase in $\mathrm{N}$ digestibility as well as to a better utilization of the dietary N. Proteolytic bacteria count was increased and the flow of nonmicrobial non-ammonia $\mathrm{N}$ tended to be higher for cows fed YC (Putnam et al 1997). The nutritional value of date-pits is based on their dietary fibre content, which makes them suitable for the preparation of fibre-based foods, such as bread, biscuits, and cakes; and dietary supplements (Larrauri et al 1995) and Date-pits fibre could be used as an alternative to wheat bran, and it may provide a valuable contribution to dietary fibre intakes (Larrauri et al 1995). Finely, breads containing the fine date-pits fibre had higher dietary fibre contents than wheat bran controls, but lower desired colour, flavour, odour, chewiness, uniformity and overall acceptability of sensory scores (Najafi, 2011).

Golshan et al (2017) concluded that date seeds can be used as a functional food ingredient because they are a good source of dietary fiber, phenolic compounds and antioxidant activity. In addition, date seeds contain a considerable amount of food ingredients such as protein and minerals. Therefore, the potential uses of date seed in different industries are promising. Date seed presents a number of challenges. However, date seeds are available at low or no cost and the seed oil extraction may be feasible and worth consideration.

\section{Rumen and blood parameters}

Results obtained in Table (8) indicated that Effect of replacement concentrate with date seed untreated and treated on rumen and blood parameters.

The rumen parameters in metabolic trail indicated that $\mathrm{PH}$ and $\mathrm{NH}_{3}$ recored no differences $(P>0.05)$ in all rations experiement but TVFA's was the highest value in ration1 (R1) control without date seed.

Differences in serum total protein, urea and GOT (AST) concentration in R3 recorded the highest values while in $R 1$ and $R 2$ were aproxmatelly the same values might be attributed to synthesis liver function and higher digestibility of $\mathrm{CP}$ and $\mathrm{OM}$ of tested rations, which indicated better utilization of dietary protein owing to replecements concentrate by untreated and treated date seeds in rations. These results were found that serum albumin and creatinine concentration was no significantly differences in all rations while GPT (ALT) values were high significantly in ration 2 contain untreated date seed then $R 1$ and $R 3$, respectively.

Table 8. Effect of replacement concentrate with untreated date seed and treated on rumen and blood parameters

\begin{tabular}{|c|c|c|c|c|}
\hline Item & $\mathbf{R 1}$ & $\overline{R 2}$ & R 3 & \pm ISE \\
\hline \multicolumn{5}{|c|}{ rumen parameters } \\
\hline pH & 6.96 & 6.76 & 6.81 & 0.06 \\
\hline TVFA's(meq/100ml) & $9.16^{a}$ & $8.10^{b}$ & $8.06^{b}$ & 0.15 \\
\hline $\mathrm{NH} 3(\mathrm{mg} / \mathbf{1 0 0 m l})$ & 14.95 & 14.86 & 14.91 & 0.21 \\
\hline \multicolumn{5}{|c|}{ blood parameters } \\
\hline Total protein(g /dl) & $2.96^{\mathrm{c}}$ & $3.08^{b}$ & $4.85^{a}$ & 0.15 \\
\hline Albumen (g/dl) & 2.16 & 2.42 & 2.47 & 0.10 \\
\hline Urea & $0.23^{c}$ & $0.30^{\mathrm{b}}$ & $0.48^{a}$ & 0.01 \\
\hline GPT(ALT)IU/L & $0.41^{b}$ & $0.51^{a}$ & $0.39^{b}$ & 0.02 \\
\hline GOT(AST)IU/L & $0.47^{c}$ & $0.63^{b}$ & $0.70^{a}$ & 0.04 \\
\hline Creatinine & 1.36 & 1.33 & 1.42 & 0.17 \\
\hline
\end{tabular}

$a, b$ and $c$ : means in the same rows with different superscripts differed significantly at $(p<0.05)$.

Where:

R1: $50 \%$ cocentrate $+50 \%$ rice straw

R2: $25 \%$ cocentrate $+25 \%$ date seed untreated $+50 \%$ rice straw

R3: $25 \%$ cocentrate $+25 \%$ date seed treatment 2

( Thermonospora fusca) $+25 \%$ rice straw

However total protein in this study was lie within the normal range. In general from these results, it could be noticed that the ration 3 (R3) which cont treated date seed (25\%) trended to significantly $(\mathrm{P}<0.05)$ affected in some blood parameters.

The demands of animal feed are increasing globally and date-pits can be used as an alternative feed. Date-pits could be a non-traditional carbohydrate sources in animal feed. Studies were conducted to use date-pits as a feed for sheep (Aldosari et al 1995). Date-pits were used in animal feed to enhance growth (Elgasim et al 1995).

These results came on line with those obtained by Abd El-Galil (2008). In most date producing 
countries, date seeds are discarded or used on a small scale as animal feed (Habib et al 2013).

\section{CONCLUSION}

It can be concluded that, in this study, It's possible to replace\% concentrate (R1) with $50 \%$ untreated date seeds (R2) or $50 \%$ treated date seeds (R3) as source of energy and protein in experimental rations. In addition that ration $\mathrm{R} 3$ containing using treated date seed was more effective on Invitro digestibility and digestion coefficient compared the other rations (R1 and R2). It could be use successfully untreated and treated date seeds by $50 \%$ replacement of concentrate to increase crude fiber, nutrients digestibility and nutritive value, while no effects on ruminal and blood parameters.

\section{REFERENCES}

Akin D.E., Morrison, W.H., Rigsby L.L., Gamble G.R., Sethuraman A. and Eriksson K.E.L., 1996. Biological delignification of plant components by the white rot fungi Ceriporiopsis subvermispora and Cyathus stercoreus. Anim. Feed Sci. Technol. 63, 305-321.

Al-Ani, A.N. and Farhan F.S.M.A., 2009. The effect of various sources of nitrogen with Date stones in fattening diets of Awassi lambs. Egyptian J. Nutrition and Feeds, Special Issue, 285-289.

Aldosari M.N., Al-Hozab A.A., Hmeidan M. and Alothaymeen I., 1995. Discarded dates and wheat straw as ingredients in the rations of growing sheep. Arab Gulf J. Sci. Res., 13, 123-131.

Al-Farisi, M. A. and Lee, C.Y., 2014. Enrichment of date paste. Journal of Human Nutrition and Food Science 2, 1-6.

Al-Shanti, H.A., Kholif, A.M., Al-Shakhrit, K.J., Al-Banna, M.F. and Abu Showayb, I.E., 2013. Use of crushed date seeds in feeding growing Assaf lambs. Egyptian Journal of Sheep and Goat Sciences, 8 (1), 65-73.

Al-Yousef Y., Belyea R.L. and Vandepopuliere, J.M., 1986. Sodium hydroxide treatment of date pits, Working Paper. Proceedings of Second Symposium on Date Palms, 3-6 March 1986, Date Palm Research Centre, King Faisal University, Al-Hassa, Saudi Arabia, pp. 103-104.

A.O.A.C. , 1995. Association of Official Agricultural Chemists. Official Methods of Analysis. Washington D.C., USA.
A.T.C.C., 1992. American Type Culture Collection Catalogue of Bacteria and Bacterophages (18 ${ }^{\text {th }}$ Ed.), USA.

Bakker, H., Zhou, G.F. and Yang, H., 1995. Mechanically driven disorder and phase transformations in alloys. Prog. Mater. Sci., 39, 159241.

Barnett, A.J. and Reid, R.C., 1956. Studies on the production of volatile fatty acids from the grass by rumen liquor in an artificial rumen VFA production from grass. J. Agri. Sci., 48, 131-161.

Basuni, A.M.M. and AL-Marzooq, M.A., 2010. Production of mayonnaise from date pit oil. Food and Nutrition Sciences 2, 3-8.

Beauchemin, K.A., Colombatto D., Morgavi D.P. and Yang W.Z., 2003. Use of exogenous fibrolytic enzymes to improve feed utilization by ruminants. J. Anim. Sci., 81, E37-E47.

Blummel, M., Steingas, H. and Becker, K. 1997. The relationship between in vitro gas production, in vitro microbial biomass yield and $\mathrm{N}$ incorporation and its implications for the prediction of voluntary feed intake of roughages. British J. Nutr., 77, 911-921.

Colombatto D., Moulda F.L., Bhat M.K. and Owen E., 2007. Influence of exogenous fibrolytic enzyme level and incubation $\mathrm{pH}$ on the in vitro ruminal fermentation of alfalfa stems. Anim. Feed Sci. Technol., 137, 150-162.

Conway, E.F., 1963. Modification analysis and volumetric error. Rev. ED. Look Wood. London.

Datt, C. and Singh G.P., 1995. Effect of protein supplementation on in vitro digestibility and gas production of wheat straw. Indian J. Dairy Sci., 48, 357-361.

Dawson, K.A., 1993. Probiotics and Enzymes in Ruminant Nutrition. In: Enzymes in Animal Nutrition, Wenk, C. and M. Boessinger (Eds.). Institute fur Nutztierwissenschaften, Zurich, Switzerland, $89 \mathrm{p}$.

Duncan D.B., 1955. Multiple range and multiple Ftest. Biometrics, 11, 1-42.

Elgasim E.A., Al Yousef Y.A. and Hueimda A.M., 1995. Possible hormonal activity of date pits and flesh fed to meat animals. Food Chem., 52, 149-152.

Elghandour M.M.Y., Vázquez Chagoyán, J.C., Salem, A.Z.M., Kholif, A.E., Martínez Castañeda, J.S., Camacho L.M. and CerrilloSoto M.A., 2014. Effects of Saccharomyces cerevisiae at direct addition or pre-incubation on In vitro gas production kinetics and degradability 

with bacteria

of four fibrous feeds. Ital. J. Anim. Sci. 13, 295301.

Etab R.I. Abd El-Galil. 2014. Using biological additives to manipulate rumen fermentation and improve baladi goats performance. Egypt. J. Nutr. Feeds, 17, 29-42.

Etab R.I. Abd El-Galil. 2008. Effect of bacterial treatments on chemical composition, cell wall constituents and digestibility of rice straw. Egyptian J. Nutrition and Feeds. 11(3), 497-510.

Etab R.I. Abd El-Galil. 2006. Effect of biological treatments on silage and feeding value of roughages in ruminants. Ph.D. Thesis, Faculty of Agriculture. Ain Shams University, Cairo, Egypt. pp. 43-47.

Gado, H.M. and Etab R.I. Abd El-Galil, 2009. Evaluation differences of some ruminal bacteria by In vitro dry matter, cellulose and hemicellulose disappearance rate and extent of bagasse. Egyptian J. Nutrition and Feeds. 12 (3), 359372.

Getachew, G., Makkar, H.P.S. and Becker K., 2002. Tropical browses: Contents of phenolics compounds, In vitro gas production and stoichiometric relationship between short chain fatty acid and In vitro gas production. J. Agric. Sci., 139, 341-352.

Golshan Tafti, A., Solaimani Dahdivan, N. and Yasini Ardakani, S.A., 2017. Physicochemical properties and applications of date seed and its oil. International Food Research J. 24(4), 1399-1406.

Guizani, N., Suresh, S. and Rahman, M.S., 2014. Polyphenol contents and thermal characteristics of freeze-dried date-pits powder. Paper Presented at the International Conference of Agricultural Engineering, Zurich.

Habib, H. M., Kamal, H., Ibrahim, W.H. and AlDhaheri, A.S. 2013. Carotenoids, fat soluble vitamins and fatty acid profiles of 18 varieties of date seed oil. Industrial Crops and Products 42: 567-572.

Henry, R.J., 1964. Clinical chemistry, principles and techniques, $2^{\text {nd }}$ Ed., Harper and Row, 525. p.

Henry, R.J., 1974. Clinical Chemistry, Harper and Row Publishers, New York, USA, 181 p,

Hristov, A.N., Oh, J., Firkins, J.L., Dijkstra J., Kebreab E., Waghorn G., Makkar H.P., Adesogan A.T., Yang W. and Lee C., 2013. Special topics: mitigation of methane and nitrous oxide emissions from animal operations: I. A review of enteric methane mitigation options. J. Anim. Sci., 91, 5045-5069.
Ingale, A.G. and Chaudhari A.N., 2013. Biogenic synthesis of nanoparticles and potential applications: An eco-friendly approach. J. Nanomed. Nanotechol., 4, 165-175.

Iravani, S., Korbekandi H., Mirmohammadi S.V. and Zolfaghari B., 2014. Synthesis of silver nanoparticles:Chemical, physical and biological methods. Res. Pharm. Sci., 9(6), 385-406.

Kaiser, D.L., Standridge, S., Friedersdorf L., C. Geraci L., Kronz F., Meador, M.A. and Stepp, D.M., 2014. National Nanotechnology Initiative Strategic Plan by National Science and Technology Council Committee on Technology. Subcommitte on Nanoscale Science, Engineering and Technology. $30 \mathrm{P}$.

Keller F.A., Hamillton, T.E. and Nguyon Q.A., 2003. Microbial pretreatment of biomass potential for reducing severity of thermo-chemical biomass pretreatment. Appl. Biochem. Biotechnol. 105, 27-41.

Larrauri J.A., Borroto B., Perdomo U. and Tabares Y. 1995. Manufacture of a powdered drink containing dietary fibre: FIBRALAX. Alimentaria, 260, 23-25.

Lina, T., Jianyang J., Fenghua Z., Huiying $\mathbf{R}$. and Wenli, L. 2009. Effect of nano-zinc oxide on the production and dressing performance of broiler. Chinese Agricultural Science Bulletin, 2, 003-011.

Maynard. E.A., Looshi J.K., Hintz, H.S. and Warner, R.G., 1979. Animal Nutrition Mc H-B Book Co. Inc. Ny, USA, pp. 45-50.

Menke H.H. and Steingass H., 1988. Estimation of the energetic feed value obtained from chemical analysis and in vitro gas production using rumen fluid. Anim. Res. Dev., 28, 7-55.

N.R.C., 1985. National Research Council, Nutrition requirements of sheep. $6^{\text {th }}$ Revised Ed. National Academy Press. Washington. D.C, pp. 30-35.

Najafi M.B.H. 2011. Date seeds: a novel and inexpensive source of dietary fiber. International Conference on Food Engineering and Biotechnology, IPCBEF, 9, 323-326.

Newman, M.D., M. Stotland and Ellis, J.I., 2009. The safety of nanosized particles in titanium dioxide- and zinc-oxide based sunscreens. J. Am. Acad. Dermatol., 61(4), 685-692.

Patton, C.J. and Crouch S.R. 1977. Spectrophotometric and kinetics investigation of the bertha lot reaction for the determination of ammonia. Anal. Chem., 49, 464-469.

Putnam, D.E., Schwab, C.G., Socha, M.T., N.I. Whitehouse, Kierstead N.A. and Garthwaite 
B.D., 1997. Effect of yeast culture in the diets of early lactation dairy cows on ruminal fermentation and passage of nitrogen fractions and amino acids to the small intestine. J. Dairy Sci., 80, 374-384.

Remesy, C., Demigne C. and Morand C., 1995. Metabolism of short-chain fatty acids in the liver. In: Cummings, J.H., Rombeau, J.L., Sakata, T., (eds), Physiological and clinical aspects of short- chain fatty acids, (Cambridge University Press, Cambridge), pp. 171-190.

Sahoo, A., Swain, R.K., Mishra S.K. and Jena, B., 2014a .Serum biochemical indices of broiler birds fed on inorganic, organic and nano zinc supplemented diets. Int. J. Recent Sci. Res., 5(11), 2078-2081.

Sahoo, A., Swain, R.K. and Mishra, S.K. 2014 b. Effect of inorganic, organic and nano zinc supplemented diets on bioavailability and immunity status of broilers. Int. J. Adv. Res., 2(11), 828837.

SAS, 1998. Statically Analysis SAS User's Guide: Statistics SAS Institute Inc. Ed. Cary, NC.

Shem, M.N., Orskov E.R. and Kimambo A.E. 1995. Prediction of voluntary dry-matter intake, digestible dry-matter intake and growth rate of cattle from the degradation characteristics of tropical foods. Anim. Sci., 60, 65-74.

Siegel, R.W., 1991. Processing of Metals and Alloys. In: R.W. Cahn (Ed). Materials Science and Technology.15, 583-588.

Szumacher-Strabel, M., Potkanski, A., Kowalczyk J., Cieslak, A., Czauderna M., Gubala M . and Jedroszkowiak P., 2002. The influence of supplemental fat on rumen volatile fatty acid profile, ammonia and $\mathrm{pH}$ level in sheep fed a standard diet. J. of Animal and Feed Sciences, 11(4), 577-587.
Te-Hsing, W., Yi-Der T. and Lie-Hang S., 2007. The novel methods for preparing antibacterial fabric composites containing nano-material. Solid State Phenom., 124(12), 1241-1244.

Van Soest, P.J. and Breston, J. 1979. Systems of Analysis for Evaluation Fibrous Feeds In: Standardization of Analytical Methodology for Feed, USA. 49 p.

Wallace, R.J. and Newbold, C.J. 1992. Probiotics for Ruminants. In: Probiotics: The Scientific Basis, Fuller, R. (Ed.). Chapman and Hall, London, pp. 317-363.

Wallace, R.J. and Newbold C.J., 1993. Rumen Fermentation and its Manipulation: The Development of Yeast Culture as Feed Additives. In: Biotechnology in the Feed Industry, Lyons, T.P. (Ed.). Alltech Technical Publications, Nicholasville, KY., 173 p.

Warner, A.C.J., 1964. Production of volatile fatty acids in the rumen. Methods of measurements. Nutr. Abst. and Rev., 34, 339-342.

Williams, P.E., C.A. Tait, G.M. Innes and C.J. Newbold, 1991. Effects of the inclusion of yeast culture (Saccharomyces cerevisiae plus growth medium) in the diet of dairy cows on milk yield and forage degradation and fermentation patterns in the rumen of steers. J. Anim. Sci., 69, 30163026.

Yang, Z.P. and Sun L.P., 2006. Effects of nanometre $\mathrm{ZnO}$ on growth performance of early weaned piglets. J. Shanxi Agric. Sci., 3, 024030.

Yu H., Guo G., Zhang X., Yan K., Xu C., 2009. The effect of biological pretreatment with the selective white-rot fungus Echinodontium taxodii on enzymatic hydrolysis of softwoods and hardwoods. Bioresour. Technol. 100, 5170-5175. 


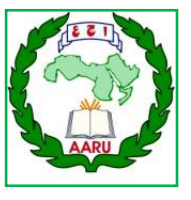

المؤتمر الرابع عثر لبحوث التنمية الزراعية،

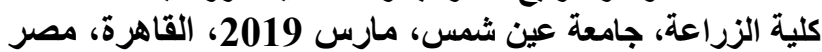

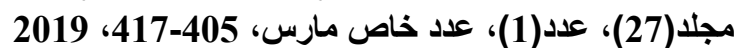

Website: http://strategy-plan.asu.edu.eg/AUJASCI/

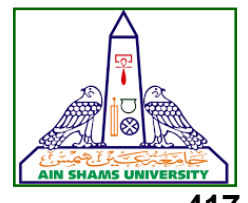

تأثير تغذية الاغنام بنوى البلح المعامل بالبكتيريا على قابيلية الهضم ويعض معايير الاداء

[38]

\author{
شيماء سليم سلامة- عتاب رمضان إبراهيم عبدالجليل- نصر السيد البرديني \\ قسم الإنتاج الحيواني - كلية الزراعة- جامعة عين شسس- ص.ب 68- حائق شبرا 11241 - القاهرة- دصر \\ "Corresponding author: selimshimaa@yahoo.com
}

Received 11 December, 2018, Accepted 20 January, 2019

إنتاج الغاز الكلى - الامونيا، الأحماض الدهنية الطيارة

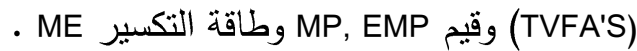
حيث كانت قيم الاختلاف بين العليقة المطابقة

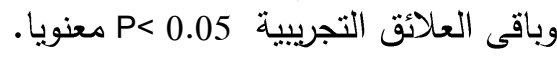

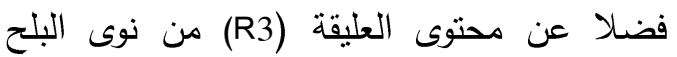
DM,OM,CF, المعامل بالمعاملة الثانية حقق اعلى فئل فئة

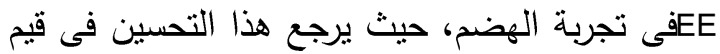

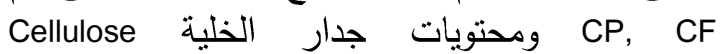
NDF , ADF , Hemicellulose زيادة بكتيريا الكرش الخلوية.

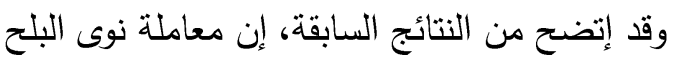

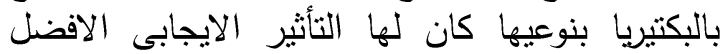

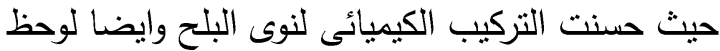
تحسن في نتائج تجربة الهضم المعملية (In vitro)

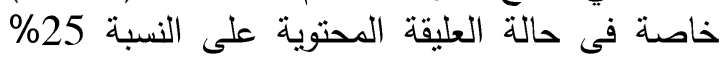
من المادة الجافة الكلية، حيث الظهرت النية النتائج أن السلالة (Theromonospora Fusca) كانت الإنة الإنل

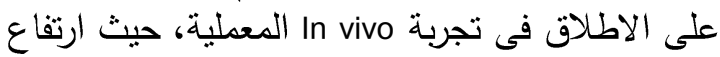
قيم ADF,OM, DM, النيتروجين قى المعاملة بالية بالبكتريا

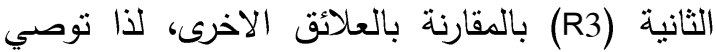

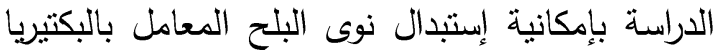
فheromonospora

دون التأثير سلبا على سائل الكرش او معاملات

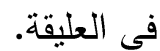

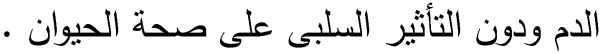

الكلمات الدالة: نوى البلح، بكتريا، أغنام، التجربة

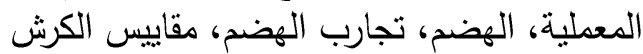

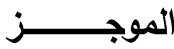

يهرف هذا البحث الى دراسة ناثير نوى البلح بنوعين من البكتيريا الخلوية تسمى Acetobacter) Xylinum \& Theromonospora Fusca) من الاغنام وتقييم الاختلافات بين هاتين المعاملتين من

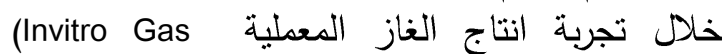
production )

وتجربة الهضم العملية حيث تم تقييم تأثثر إضافة

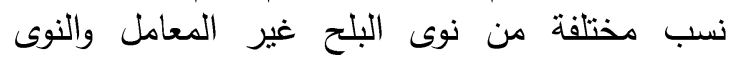
المعامل بنوعية للعليقة الحيوانية على قيم NDF , ADF للتجربة DM , OM , Hemicellulose , Cellulose , المعملية (In vitro) بعد التحضين لمدة 24 ساعة حيث

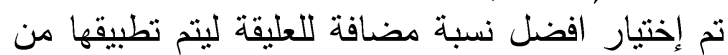
خلال تجربة الهضم المعلية على الاغنام.

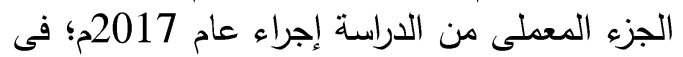

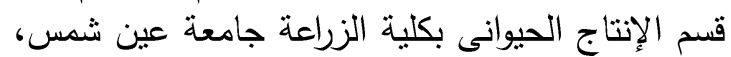

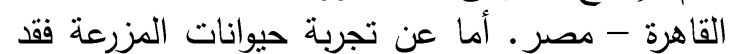
تمت فى معهد بحوث الإنتاج الحيوانى.

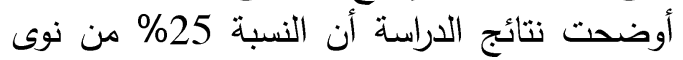

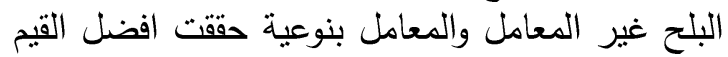
NDF , ADF , Hemicellulose, Cellulose تكسير الئحل بعد 24 ساعة وخاصة المعاملة الثانية اى نوى البلح المعامل ب(Theromonospora Fusca). اظهرت التجربة المعلية أن تركيزات متزايدة من نوى البلح غير المعامل والمعامل لم يؤثر على تلى قيم الأس الهيدروجينى PH بينما كانت مؤثرة فى حالة على الئل 